\title{
Onthophagus landolti and Canthon indigaceus chevrolati (Coleoptera: Scarabaeinae) are attracted to the feces of ivermectin-treated cattle in the Mexican tropics
}

\author{
Roger Iván Rodríguez-Vivas ${ }^{1}$, Gertrudis del Socorro Basto-Estrella ${ }^{1}$, Enrique Reyes-Novelo ${ }^{2}$, \\ Luis Carlos Pérez-Cogollo ${ }^{3}$, William Arcila-Fuentes ${ }^{1}$, Melina Ojeda-Chi ${ }^{1}$ \& Imelda Martínez-M. ${ }^{4}$ \\ 1. Facultad de Medicina Veterinaria and Zootecnia, Universidad Autónoma de Yucatán, Carretera Mérida-Xmatkuil Km. \\ 15.5,97100 Mérida, Yucatán, México; rvivas@correo.uady.mx, gertrudisbasto@hotmail.com, \\ w.arcilaf35@outlook.com,mojeda_93@hotmail.com \\ 2. Centro de Investigaciones Regionales "Dr Hideyo Noguchi", Av. Itzaes No. $490 \times 59$, Col. Centro, 97000 Mérida, \\ Yucatán, México; enrique.reyes@correo.uady.mx \\ 3. Departamento de Ciencias Pecuarias, Facultad de Medicina Veterinaria and Zootecnia, Universidad de Córdoba, \\ Ciudad Universitaria, Carrera 6 No. 76-103, 354, Montería, Colombia; luisperez@correo.unicordoba.edu.co \\ 4. Instituto de Ecología A.C., Carretera Antigua a Coatepec 351, El Haya, 91070 Xalapa, Veracruz, México; \\ imelda.martinez08@gmail.com
}

Received 09-IV-2018. Corrected 08-VIII-2018. Accepted 03-XII-2018.

\begin{abstract}
Ivermectin (IVM) is widely used for parasite control in livestock in the tropics. Residual IVM in feces conserves its insecticide activity for weeks and can harm dung beetle (DB) species. Attraction to the feces of IVM-treated cattle was tested using the DB species Onthophagus landolti (Harold) and Canthon indigaceus chevrolati (Harold) as models. Experiments were done under controlled laboratory conditions, semi-controlled field conditions and uncontrolled field conditions. Olfactometers were used in the controlled and semi-controlled trials. The control treatment was baited IVM-free feces, and the experimental treatments were the feces of cattle treated with $1 \%$ IVM (subcutaneous administration; single, $0.2 \mathrm{mg} / \mathrm{kg}$ bw dosage) and collected at 5, 14, 21 and 28 days post-treatment. The uncontrolled field trial involved pitfall traps baited with IVM-free feces or feces from IVM-treated cattle collected five days post-treatment. Under controlled and semi-controlled conditions, the feces of IVM-treated cattle (at 5, 14, 21 or 28 days post-treatment) attracted more $O$. landolti and $C$. i. chevrolati individuals than IVM-free feces $(\mathrm{P}<0.05)$. The same response occurred under uncontrolled conditions. This clear attraction for IVM-containing cattle feces by the studied DB species highlights that incorrect IVM use may pose a risk to DB communities in cattle production systems.
\end{abstract}

Key words: Ivermectin; cattle feces; dung beetles; attraction; controlled conditions; field conditions; olfactometer.

Rodríguez-Vivas, R. I., Basto-Estrella, G. S., Reyes-Novelo, E., Pérez-Cogollo, L. C., ArcilaFuentes, W., Ojeda-Chi, M. \& Martínez-M., I. (2019). Onthophagus landolti and Canthon indigaceus chevrolati (Coleoptera: Scarabaeinae) are attracted to the feces of ivermectintreated cattle in the Mexican tropics. Revista de Biología Tropical, 67(1), 254-265.

In temperate and tropical areas of the world, dung beetles belonging to the subfamily Scarabaeinae (Floate, 2011) perform a large part of the dung removal from the ground. This function accelerates the incorporation of dung nutrients into the soil, contributing to the maintenance of grassland productivity, and controlling natural animal pests (Nichols et al., 2008).

Macrocyclic lactones (ML) are the most widely used deparasitizing treatment in cattle 
for control of endo- and ectoparasites (Rodríguez-Vivas et al., 2010; Davey, Pound, Miller, \& Klavons, 2010). Of the ML, ivermectin (IVM) is currently the most popular compound in tropical cattle ranching (Rodríguez-Vivas et al., 2010). Its high liposolubility, means 90 $\%$ of the IVM applied in cattle is eliminated in the feces, with insecticide activity intact (Rodríguez-Vivas et al., 2010). Maximum concentration of excreted IVM occurs in feces produced three days post-treatment (dpt), although detectable concentrations remain in feces up to $28 \mathrm{dpt}$ (Pérez-Cogollo, Rodríguez-Vivas, Reyes-Novelo, Delfín-González, \& MuñozRodríguez, 2017).

Dung beetles (DB) use animal feces as a resource in their feeding and reproduction cycles. Ingestion with IVM can cause lethal and sublethal effects in DB (reduction of DB egg production and larval development) (Errouissi \& Lumaret, 2010; Webb, Beaumont, Nager, \& McCracken, 2010; Floate, 2011; Wall \& Beynon, 2012; Pérez-Cogollo, RodríguezVivas, Delfín-González, Reyes-Novelo, \& Ojeda-Chi, 2015; González-Tokman et al., 2017; Martínez, Lumaret, Ortiz Zayas, \& Nassera Kadiri, 2017a). Administration of IVM to livestock herds in a region can lead to drastic decreases in DB population densities and even reduction in the number of DB species (Martínez, Ramírez-Hernández, \& Lumaret, 2017b; Verdú et al., 2017). This is especially the case if IVM treatment coincides with DB reproduction periods when stages more sensitive to IVM (e.g. eggs and larvae) can come into contact with and/or consume feces containing IVM residues (Errouissi \& Lumaret, 2010; BastoEstrella, Rodríguez-Vivas, Delfín-González, \& Reyes-Novelo, 2014; Pérez-Cogollo et al., 2015; Martínez et al., 2017a).

Reductions in DB species diversity and population sizes can have long-term effects on the elimination processes of cattle feces from the surface of grasses (Floate, Wardhaugh, Boxall, \& Sherratt, 2005; Verdú el al., 2017). Among other effects, this can reduce and even delay grass growth, altering the ecological services of these insects, which are so vital to cattle system sustainability (Dadour, Cook, \& Neesam, 1999; Lee \& Wall, 2006; Steinfeld et al., 2006). Indeed, the ecological services of DB species in cattle grassland ecosystems is so important they are used as a research taxon in applied biodiversity conservation research. Scarabaeinae DB assemblages are trustworthy indicators of ecological disturbance and climate change (Nichols \& Gardner, 2011).

Many studies have addressed IVM's lethal and sublethal effects in different DB species in response to ingesting the feces of treated animals. These effects may be exacerbated if the feces are more attractive to the beetles (Floate, 2007; Errouissi \& Lumaret, 2010). Some studies involving field experiments using pitfall traps have documented that, within the same coprophagous insect community, IVM excreted in feces can have an attraction effect on some taxa and a repellant effect on others (Lumaret et al., 1993; Holter, Sommer, \& Grønvold, 1993a; Floate, 1998a; Sutton, Bennett, \& Bateman, 2014). Distinguishing which species in a community experience attraction is important because if these are the dominant species it can seriously impact excrement recycling in ranching areas.

Considering this situation and in an effort to generate baseline data to contribute to responsible ML management in cattle production systems, the aims of the present study were to use field and laboratory experiments to evaluate the attractive effect of feces from IVM-treated cattle to the DB species Onthophagus landolti (Harold, 1880) and Canthon indigaceus chevrolati (Harold, 1868).

\section{MATERIALS AND METHODS}

Study site: Due to their dominance in DB communities in the study region, the species $O$. landolti and $C$. indigaceus chevrolati were used as models to measure feces attraction (BastoEstrella, Rodríguez-Vivas, Delfín-González, \& Reyes-Novelo, 2012).

From January to August 2017 individuals of these two species were collected directly from cattle dung on a ranch in Tizimin 
municipality, in the state of Yucatan, Mexico $\left(21^{\circ} 15^{\prime} 8.44^{\prime \prime} \mathrm{N}-88^{\circ} 6^{\prime} 4.65^{\prime \prime} \mathrm{W}\right)$. The production system was semi-intensive with the main feed grasses being Brachiaria brizantha (Hochst. ex A. Rich.) and Panicum maximun (Jacq.) (Simon BK \& Jacobs SWL). Macrocyclic lactones had never been used for parasite control at this ranch.

Regional climate was warm subhumid with $1000 \mathrm{~mm}$ average annual rainfall and $25.8{ }^{\circ} \mathrm{C}$ annual average temperature (Orellana-Lanza, Espadas-Manrique, \& Nava-Marín, 2010). Geomorphology was predominantly a young karso-tectonic system and was classified as an undulating structural plain with dissolution and denudation, and soils dominated by lithosols, rendzinas and cambisols (Bautista, Batllori, Palacio, Ortiz, \& Castillo, 2005). Pastures in the region were surrounded by secondary vegetation in different regeneration stages, mostly semi-evergreen tropical forest and tropical seasonally flooded forest (GarcíaGil, Méndez-González, Aguilar-Cordero, \& Orellana-Lanza, 2010).

Collected individuals from the model species were carried out to the laboratory at the Biological, Agricultural and Livestock Sciences Campus (Campus de Ciencias Biológicas y Agropecuarias - CCBA) of the Autonomous University of Yucatan (Universidad Autónoma de Yucatán - UADY). During transport and initial processing, the DB were held in plastic containers $(30 \times 15 \times 10 \mathrm{~cm})$. They were sexed, examined to ensure they were mature individuals (i.e. fully developed coloring, wear on clypeals and tibial spurs, appendages complete), and taxonomically confirmed by comparison to reference specimens and bibliographic descriptions (Morón, 2003). After processing, they were placed in terrariums $(20 \mathrm{x}$ $12 \times 6 \mathrm{~cm})$ to acclimatize. They were fed with IVM-free feces and kept under controlled conditions $\left(27 \pm 3{ }^{\circ} \mathrm{C} ; 60-70 \%\right.$ relative humidity).

Cattle management for feces collection: Six beef cattle (Bos indicus x Bos taurus; $450-500 \mathrm{~kg}$ ) were used for feces collection. They had last been deparasitized at least four months prior to the experiment. Each was subcutaneously injected with $1 \%$ IVM $\left(\right.$ Ivomec $^{\circledR}$, Merial, Lot 8D164/16, Exp. 05/2019) at the manufacturer recommended dosage of $0.2 \mathrm{mg} /$ $\mathrm{kg}$ (Rodríguez-Vivas et al., 2010). Then, the animals moved to a semi-enclosed corral with a cement floor. The floor was cleaned prior to the cattle being placed there and every day during all the experiment period. Feces were collected on day 0 (control, prior to IVM treatment), and then at 5, 14, 21 and 28 days post-treatment (dpt). To avoid contamination and drying, samples were collected directly from the clean corral floor in the morning. Once collected, the feces were homogenized in an electric blender for 10 minutes and then frozen $\left(-20^{\circ} \mathrm{C}\right)$ until use. Collection frequency was done based on a previously reported curve for IVM excretion in cattle feces (Pérez-Cogollo et al., 2017).

Three experiments were done: one using an olfactometer under controlled laboratory conditions; one using an olfactometer under semi-controlled field conditions; and a third using pitfall traps in uncontrolled field conditions. The olfactometers had to be slightly modified for each tested DB species since C. $i$. chevrolati is a roller species and $O$. landolti a tunneller species.

Olfactometer for $\boldsymbol{C}$. $\boldsymbol{i}$. chevrolati: Ranjith's proposal (2007) was followed to build an active olfactometer (with constant air flow) to allow the chemical stimulus to reach the DB (Finch, 1986). It consisted in a circular plastic chamber with a main central chamber (23 cm diameter x $20 \mathrm{~cm}$ high) and a cover. Four plastic tubes $(2 \mathrm{~cm}$ diameter $\times 40 \mathrm{~cm}$ long) connected to the sides of this chamber, and at the end of each tube a square plastic container (13 x $13 \times 10 \mathrm{~cm}$ high) was attached to hold the feces used as baits. These were covered with a ventilated top for air flow. Four centimeters of soil was placed on the floor of each container. To allow the beetles to detect the volatile compounds of feces, air flow in the central chamber was helped by an extraction fan attached through a hose to the upper portion 
of the cover. This produced constant air flow down the tubes towards the central chamber. A round subchamber $(6 \mathrm{~cm}$ diameter $\times 6 \mathrm{~cm}$ high) with orifices held the beetles and allowed them to detect volatile before release into the olfactometer (Fig. 1A).

Functionality of the active olfactometer was assessed with a standardization test to determine if $C$. $i$. chevrolati were attracted to feces in the device. Feces $(80 \mathrm{~g})$ was placed in containers one and three while containers two and four were left empty. A group of $C$. $i$. chevrolati (12 males; 12 females) was placed in the subchamber for 10 min under active air circulation, and then released into the main chamber. After 30 mins, counts were done of the number of individuals, total and of each sex, in each of the four containers (feces and no feces). Ten replicates were done using different individuals in each replicate. Test conditions were controlled and designed to simulate the conditions and time during which $\mathrm{DB}$ are active under field conditions in the study area: $26 \pm 2{ }^{\circ} \mathrm{C} ; 65 \% \pm 5 \mathrm{RH}$; artificial light (60-watt bulb); and 09:00-14:00 h.

Olfactometer for $\boldsymbol{O}$. landolti: A passive olfactometer (without active air flow) was modified from Finch (1986) and used to allow $O$. landolti individuals to perceive the chemical stimulus. The primary element was a circular plastic chamber (45 $\mathrm{cm}$ diameter x $17 \mathrm{~cm}$ high) with a transparent cover with four equidistant holes ( $5 \mathrm{~cm}$ diameter), was placed $12 \mathrm{~cm}$ from the chamber's central point. Below each hole a plastic container ( $7 \mathrm{~cm}$ diameter $\times 10 \mathrm{~cm}$ high) was placed and filled with sterile soil up to 4 cm depth (Fig. 1B).

A test was run to evaluate the functionality of the passive olfactometer in attracting $O$. landolti towards feces. The holes in the top were numbered 1 through 4 . Feces $(80 \mathrm{~g})$ was placed in the containers under holes 1 and 3 , while those below holes 2 and 4 were left

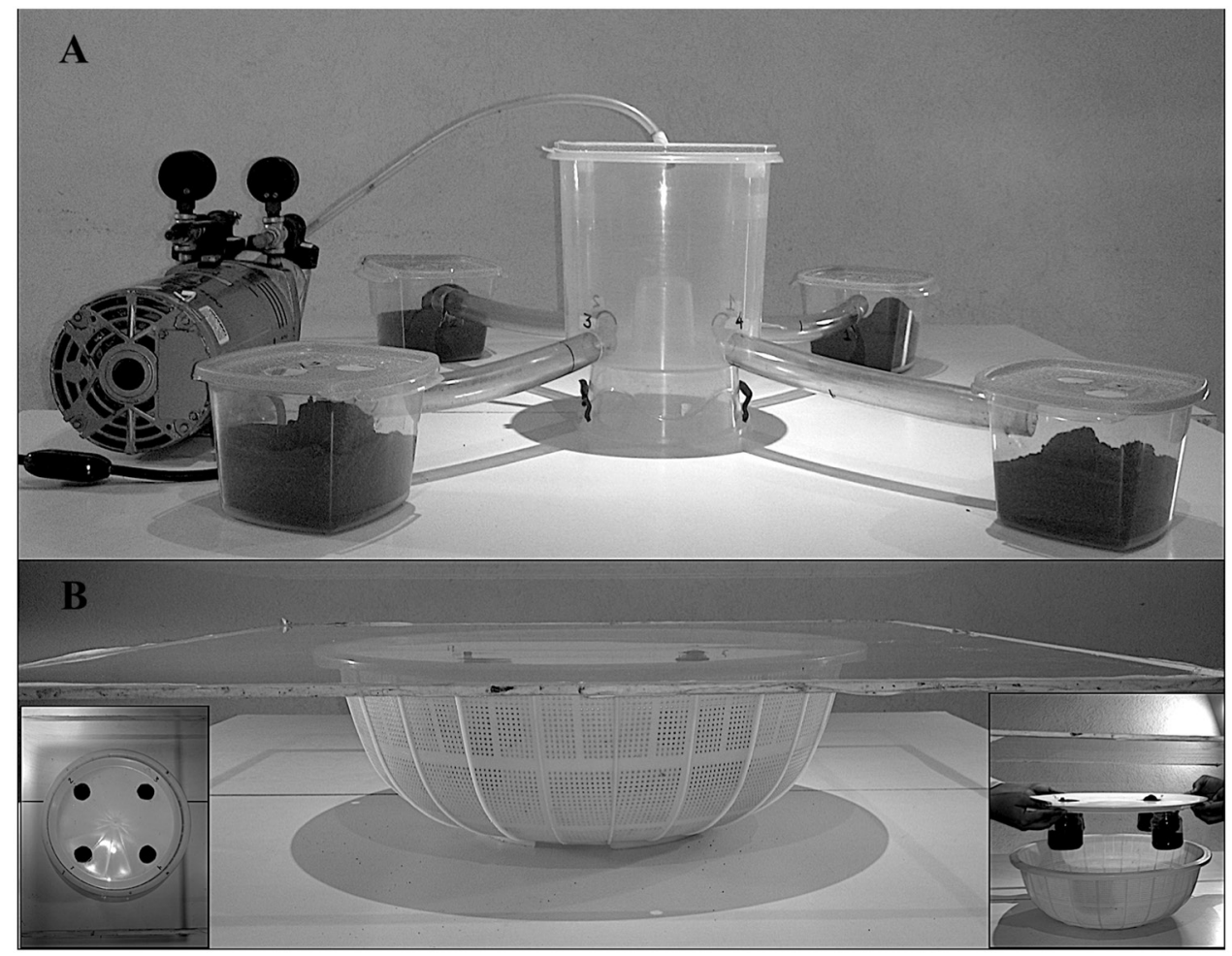

Fig. 1. Pictures of active (A) and passive (B) olfactometers used in the experiments. 
empty. A group (12 males and 12 females) of $O$. landolti was placed in a round container ( 2 $\mathrm{cm}$ diameter $\times 3 \mathrm{~cm}$ high), and this container placed in the center of the chamber. The beetles were released, and the chamber top replaced. After $60 \mathrm{~min}$ the chamber was opened, and counts done of the number of individuals, total and of each sex, that had gone to each container (with and without feces). Ten replicates were done, each with a different group of beetles. Environmental conditions were those described above for the active olfactometer.

Experiment 1a) Attraction of $C$. i. chevrolati to feces of IVM-treated cattle under laboratory conditions: Following the same method as used for active olfactometer standardization, a control treatment (80 g IVMfree feces) was placed in containers one and three while the experimental treatment $(80 \mathrm{~g}$ feces from animals treated with $1 \%$ IVM) was placed in containers two and four. Separate assays were run with feces collected on days 5 , 14, 21 and $28 \mathrm{dpt}$. Ten replicates were done of each dpt interval assay.

Experiment 1b) Attraction of $O$. landolti to feces of IVM-treated cattle under laboratory conditions: Following the same method as used for passive olfactometer standardization, a control treatment ( $80 \mathrm{~g}$ IVM-free feces) was placed in holes one and three while the experimental treatment $(80 \mathrm{~g}$ feces from animals treated with $1 \%$ IVM) was placed in holes two and four. Separate assays were run with feces collected on days 5, 14, 21 and $28 \mathrm{dpt}$. Ten replicates were done of each dpt interval assay.

Experiment 2: Attraction to feces of IVM-treated cattle under field conditions. Field trials were done at a cattle ranch (R1) in the ranching region of Yucatan $\left(21^{\circ} 15^{\prime} 8.29^{\prime \prime} \mathrm{N}\right.$ $88^{\circ} 6^{\prime} 4.64$ " W). Climate and geomorphology were the same as those described above. For $C$. $i$. chevrolati, the active olfactometer was placed on a pasture and used as described above, but without an extractor fan (used in the experiment 1a) due to lack of electricity in the test area. For $O$. landolti the passive olfactometer was placed in another pasture of the ranch and used as described above. In both type of olfactometer a control treatment $(80 \mathrm{~g}$ IVM-free feces) and experimental treatment ( $80 \mathrm{~g}$ feces from animals treated with $1 \%$ IVM) were used. Separate assays were run with feces collected on days 5, 14, 21 and $28 \mathrm{dpt}$. Ten replicates were done of each dpt interval assay.

Experiment 3: Natural attraction to the feces of IVM-treated cattle under field conditions (C. $i$. chevrolati and O. landolti). Trials were done in pastures at two ranches (Actun Ha: R1 and Santa Elena: R2) in the same region $\left(21^{\circ} 13^{\prime} 12.45^{\prime \prime} \mathrm{N}-88^{\circ} 1^{\prime} 34.77^{\prime \prime} \mathrm{W}\right)$ and with similar conditions, neither of which had a history of ML use for deparasitizing animals. Pastures used in the trials were approximately 1.5 ha in size. Grazing practices involved the use of a pasture for five days followed by a 30-day fallow period to allow for grass recovery. Animal carrying capacity was four animal units/ha, one unit being equivalent to approximately 450 $\mathrm{kg}$ live weight.

At each ranch, ten transects were laid out with $20 \mathrm{~m}$ distance between each transect (Decante \& van Helden, 2008), and two sampling points placed $20 \mathrm{~m}$ apart on each transect (adapted from Floate, 2007). At each sampling point, two pitfall traps were placed randomly (Lobo, Martin-Piera, \& Veiga, 1988). One of these traps was baited with $200 \mathrm{~g}$ of feces from non-deparasitized cattle (control) and the other with $200 \mathrm{~g}$ feces from cattle deparasitized with $1 \%$ IVM (experimental). The latter was collected at $5 \mathrm{dpt}$, which is when feces IVM concentration is highest (Pérez-Cogollo et al., 2017). Two trials were done during the rainy season (August 2017), when DB activity was highest (Basto-Estrella et al., 2012). Traps were active for eight $\mathrm{h}$ (07:00-15:00 h), after which the beetles were collected and the counts done of all C. $i$. chevrolati and O. landolti individuals in each trap. 
Data collection and analysis: For experiments 1 and 2, a generalized linear model with a Poisson error distribution was used to analyze the principal effects of three factors on the number of dung beetles attracted to feces: a) feces with two levels (from IVM-treated animals and from non-treated animals); b) beetle sex with two levels (female and male); and c) dpt with four levels (5, 14, 21 and 28). The statistical analyses were run separately for each species.

For experiment 3, a two-way ANOVA was applied to analyze the principal effects of feces with two levels (from IVM-treated animals and from non-treated animals); and ranch with two levels $\left(R_{1}\right.$ and $\left.R_{2}\right)$ on the number of dung beetles attracted to feces. To meet the assumptions required by the ANOVA, the number of beetles was log-transformed.

Post hoc comparisons were done using least squares, adjusting for error with the Bonferroni method in experiments 1 and 2, and the Tukey method in Experiment 3. Statistical significance was settled at $\mathrm{P}<0.05$. All procedures were run with the $\mathrm{R}$ ver. 3.3.2 (R Core Team, 2016).

\section{RESULTS}

Experiment 1: From the 960 individuals (480 couples) used for the experiments, 905 C. $i$. chevrolati had an accounted preference in the olfactometer (94.2\%). Differences were observed in the number of $C$. $i$. chevrolati attracted to feces from IVM-treated animals and those attracted to IVM-free feces ( $\mathrm{F}=$ 178.3, d.f. $=1, \mathrm{P}<0.0001$, deviance $=133.86$ on 144 d.f.). There were also differences in the $\mathrm{dpt} / \mathrm{IVM}$ treatment interaction $(\mathrm{F}=5.73$, d.f $=$ $3, \mathrm{P}=0.0009$ ), in which attraction to the feces of IVM-treated animals was higher at all dpt than that for IVM-free feces (Fig. 2A). For the IVM-free feces the beetles showed the lowest attraction at $14 \mathrm{dpt}(\mathrm{Z}=-3.06, \mathrm{P}=0.0021)$ and
A

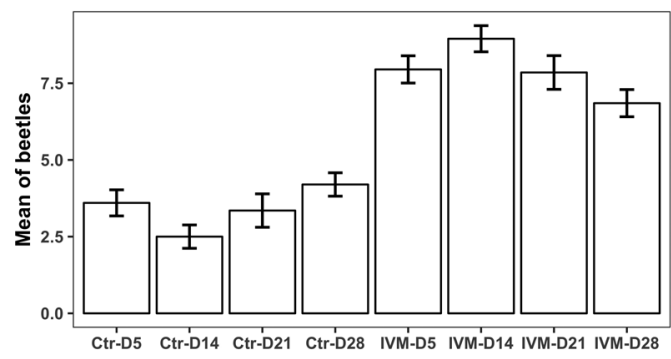

C

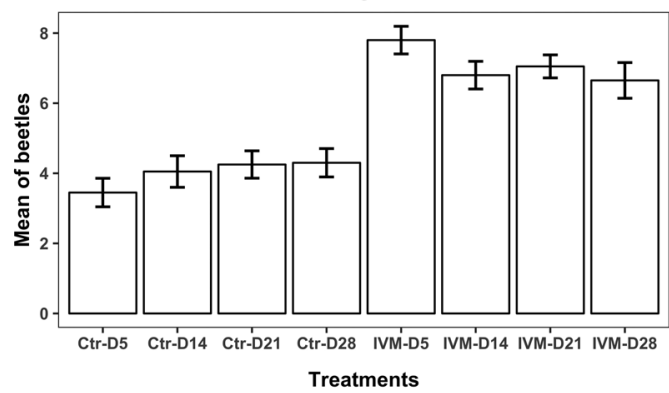

B

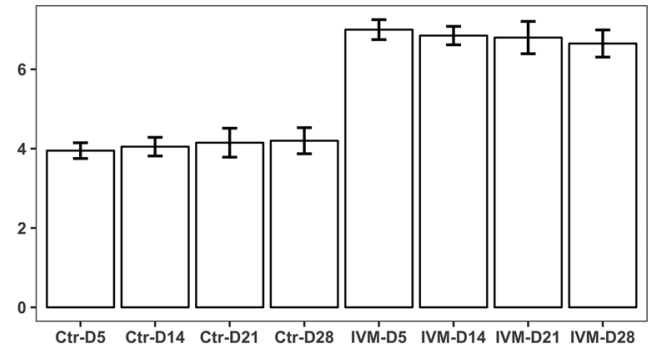

D

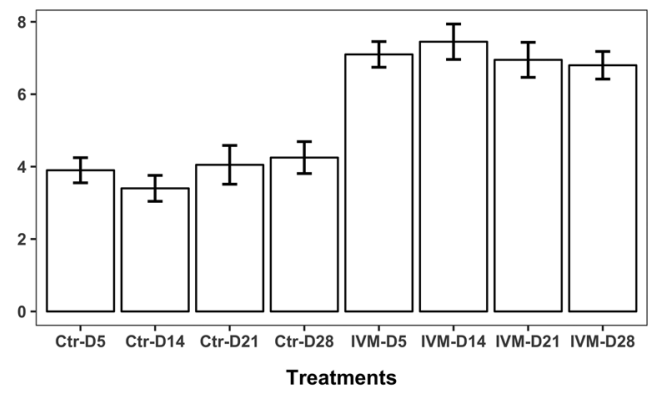

Fig. 2. Number of dung beetles attracted to feces of cattle treated with $1 \%$ ivermectin (IVM) and of untreated cattle (Ctr). Evaluations were done 5, 14, 21, and 28 days post-treatment. (A) Canthon indigaceus chevrolati, (B) Onthophagus landolti evaluated under controlled laboratory conditions. (C) C. I chevrolati and (D) O. landolti under semi-controlled field conditions. 
the highest at $28 \mathrm{dpt}(\mathrm{Z}=3.02, \mathrm{P}=0.0025)$. In the principal effects of the model, sex affected attraction $(\mathrm{F}=4.1$, d.f $=1, \mathrm{P}=0.0423)$, specifically, females were more attracted to IVM-free feces at $21 \mathrm{dpt}(\mathrm{Z}=2.11, \mathrm{P}=0.0342)$.

For O. Landolti, 873 of 960 individuals $(90.9 \%)$ had an accounted preference. The feces of IVM-treated animals attracted more beetles than IVM-free feces $(\mathrm{F}=151.2$, d.f $=1$, $\mathrm{P}<0.0001)$. Neither sex nor dpt affected attraction in this species (Fig. 2B).

Experiment 2: In the field trials using the olfactometers, 887 of $960(92.4 \%)$ C. $i$. chevrolati individuals had an accounted preference and were more frequently attracted to the feces of IVM-treated animals ( $\mathrm{F}=97.7$, d.f $=1, \mathrm{P}<0.0001$ ), with no effect of sex or dpt (Fig. 2C). From the 960 individuals of O. Landolti, 878 had an accounted preference $(91.5 \%)$ and individuals were also more attracted to the feces of IVM-treated animals $(\mathrm{F}=101.8$, d.f $=1, \mathrm{P}<0.0001)$, with no effect of sex or dpt (Fig. 2D).

Experiment 3: A total of 1162 C. $i$. chevrolati were accounted in the baited pitfall traps. The number of $C$. $i$. chevrolati was higher at $\mathrm{R}_{2}(\mathrm{~F}=73.09$, d.f $=1, \mathrm{P}<0.0001)$. At both ranches more individuals of this species were attracted to the feces of IVM-treated animals than to IVM-free feces $(\mathrm{F}=13.8$, d.f $=1, \mathrm{P}=0.0006$ ) (Fig. 3A). For O. landolti, a total of 779 beetles were attracted to the traps and the ANOVA revealed that the number of beetles was explained by both factors, ranch $(\mathrm{F}=72.2$, d.f $=1, \mathrm{P}<0.0001)$ and IVM treatment $(\mathrm{F}=87.04$, d.f $=1, \mathrm{P}<0.0001)$. Although the number of individuals did varied between ranches, the pattern of differences between treatments remained consistent between ranches (Fig. 3B).

\section{A}

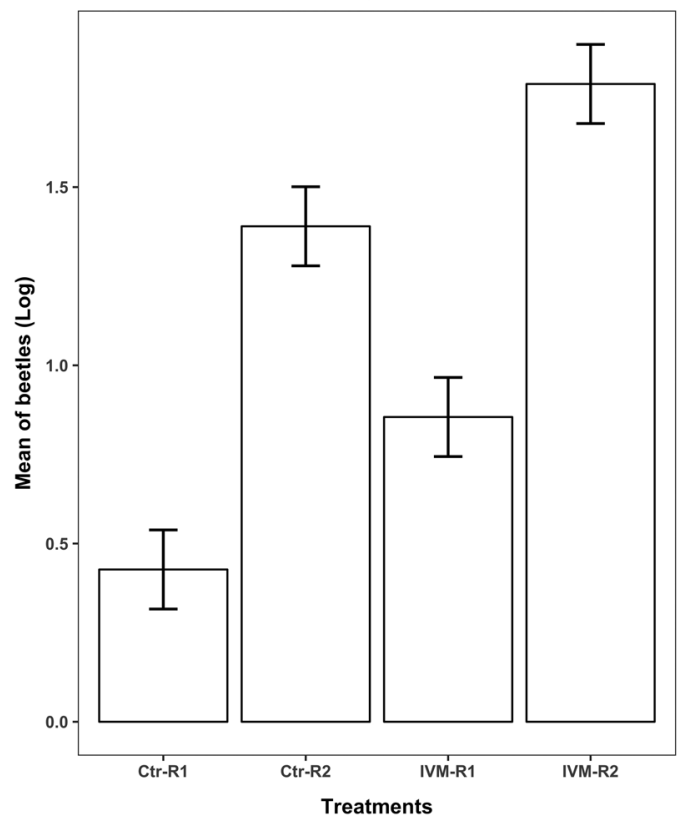

B

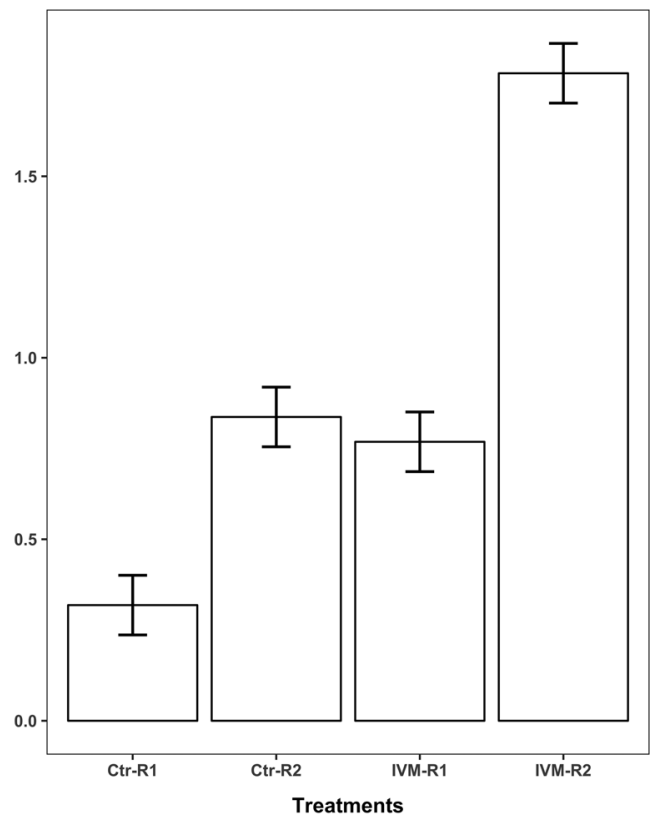

Fig. 3. Log transformed number of dung beetles attracted to feces of cattle treated with $1 \%$ ivermectin (IVM) and of untreated cattle (Ctr). (A) Canthon indigaceus chevrolati and (B) Onthophagus landolti evaluated under uncontrolled field conditions at two cattle ranches in the state of Yucatan, Mexico (Actun Ha: R1 and Santa Elena: R2) with five days posttreatment feces using baited pitfall traps. 


\section{DISCUSSION}

Both $O$. landolti and C. $i$. chevrolati were found to exhibit a notably higher attraction towards the feces of cattle treated with $1 \%$ IVM. The effect on the number of beetles attracted to those feces was clear in all experiments. The concentration of $1 \%$ IVM in the feces used in the experiments was not measured in the present study, but at this concentration and dose $(0.2 \mathrm{mg} / \mathrm{kg} \mathrm{pv})$ it is known that cattle feces contain slightly more than 800 $\mathrm{ng} / \mathrm{g}^{-1}$ at $5 \mathrm{dpt}$, decreasing to near $44 \mathrm{ng} / \mathrm{g}^{-1}$ at 28 dpt (Pérez-Cogollo et al., 2017). On behalf of this study we are taking the later quantity as an indicator of the probable amount of IVM on the feces because this concentration could oscillate between individuals, cattle breed, and animal physiological conditions. This coincides with previous reports for other DB species. Wardhaugh \& Mahon (1991) reported that the feces of IVM-treated sheep attracted more individuals of the DB species Onthophagus spp. and Euoniticellus fulvus than IVMfree sheep feces. Webb et al. (2010) recorded higher numbers of Aphodius spp. in grasslands grazed by cattle deparasitized with IVM than in grasslands where cattle were not treated with this endectocide. In a field study, BastoEstrella et al. (2014) reported similar results to the present study in that they collected more $C$. $i$. chevrolati and $O$. landolti in pastures where $1 \%$ IVM-treated cattle grazed than in pastures where the cattle had not been treated with IVM. Römbke et al. (2010) found that one out of every five studied Aphodiinae species was more attracted to IVM-containing feces. Other beetle families (e.g. Hydrophilidae and Staphylinidae) are also known to be attracted to cattle manure containing IVM residues (Floate, 1998a, b). Still several studies reporting similar results include Holter, Sommer, Grønvold, \& Madsen (1993b), Lumaret et al. (1993), Krüger \& Scholtz (1998), Suarez, Lifschitz, Sallovitz, \& Lanusse (2003), Floate (2006, 2007), Errouissi \& Lumaret (2010), Tovar, Noriega, \& Caraballo (2016).
Insects mainly use smell to detect and find different food sources (Tumlinson, Lewis, \& Vet, 1993; Pernal \& Currie, 2002). A study done in Southern Spain found that the DB Thorectes lusitanicus (Col., Scarabaeoidea, Geotrupidae) could detect the volatile compounds in acorns using its antennae's chemoreceptors (Verdú et al., 2007). Ivermectin's high polarity and molecular weight allow it to bond tightly to manure particles thus retarding its volatilization and prolonging it presence in the matrix (Floate, 2007). The manure of IVMtreated cattle exhibits different amino acid profiles than IVM-free manure; indeed, over 160 volatile compounds have been detected in the feces of IVM-treated cattle, including volatile fatty acids (VFA), sulfur, indoles, phenols, ammonium and amines (Bernal, Nozal, Salas, Galante, \& Lumaret, 1994; Mackie, Stroot, \& Varel, 1998; Dormont, Jay-Robert, Bessière, Rapiorm, \& Lumaretm, 2013). At low concentrations $(0.5-4.0 \mathrm{mg} / \mathrm{kg}$ manure) some of these compounds can attract insects (Schaper \& Liebisch, 1991; Bernal et al., 1994). Dung beetles are apparently attracted by the presence of these molecules and/or the changes they cause in the intestinal flora of treated animals (Wardhaugh \& Mahon, 1991; Lumaret et al., 1993). In O. landolti and C. $i$. chevrolati, the antennae chemoreceptors may be involved in their preference for feces containing IVM residues under both laboratory and field conditions since multiple volatile compounds are present under both circumstances (Verdú et al., 2007).

In the present study, both $O$. landolti and C. $i$. chevrolati continued to be attracted to feces containing IVM for nearly one month $(28 \mathrm{dpt})$ after treatment. This agrees with a previous study in which beetles of the genus Onthophagus were found to be attracted to the feces of IVM-treated cattle up to $25 \mathrm{dpt}$ (Wardhaugh \& Mahon, 1991; Floate, 2007).

The observed attraction of the studied DB species towards IVM-containing cattle feces highlights the potential negative effects of this endectocide in DB communities associated with cattle production systems. Ivermectin (IVM) can have lethal and sublethal effects on 
both species, mainly affecting their reproductive capacity by diminishing egg production and larval development (Pérez-Cogollo et al., 2015, 2017). This compound may also affect other functions in DB. One study showed that ingestion of low doses of IVM by Scarabaeus cicatricosus notably decreased antenna sensory capacity and caused motor difficulties, thus affecting foraging and reproductive functions (Verdú et al., 2015). This occurs because IVM interacts with glutamate-dependent chlorine channels, stimulating the flow of chlorine ions to the cell interior and modulating GABA-mediated neurotransmission in nerve and muscle cells. Ivermectin inhibits this neurotransmission, consequently paralyzing somatic musculature (Duce \& Scott, 1985; Kane et al., 2000), and blocking the olfactory and mechanoreceptive capacities (Panek, Meisner, \& Torkkeli, 2003; Pfeiffer, Torkkeli, \& French, 2013).

That $O$. landolti and $C$. $i$. chevrolati are attracted to IVM-containing feces is worrisome since IVM has known negative effects in different DB species (Verdú et al., 2015; PérezCogollo et al., 2017; Martínez et al., 2017a). Results have shown that attraction of dung from IVM treated animals to these two species, represent a potential threat to their population sizes or dynamics, that may have a negative impact in the agroecosystem because these two species are recognized as abundant in the Mexican tropical areas (as shown by Basto-Estrella et al., 2012), so DB community can be diminishing as IVM use increase in the frequency of application or dosses as is already shown by some field studies were this drug is used (look Basto-Estrella et al., 2014), turning a potential environmental adverse effect on dung removal and other ecosystem functions of DB community in tropical agroecosystems (Steinfeld et al., 2006; Nichols et al., 2008; Errouissi \& Lumaret, 2010; Wall \& Beynon, 2012).

Ethical statement: authors declare that they all agree with this publication and made significant contributions; that there is no conflict of interest of any kind; and that we followed all pertinent ethical and legal procedures and requirements. A signed document has been filed in the journal archives.

\section{ACKNOWLEDGMENTS}

The research reported here was financed by a CONACYT-Ciencia Básica (253578) grant. The authors thank Jorge Pacho, Suleyma Anaí Orozco Benítez, María Ludivina May Ortis, Andreyna Arisbe Arceo Morán, Georgina Fernanda Mendoza López, and Coral Arely García Ceballos for their assistance with the bioassays.

\section{RESUMEN}

Onthophagus landolti y Canthon indigaceus chevrolati (Coleoptera: Scarabaeinae) son atraídos por las heces de ganado tratado con ivermectina en el trópico mexicano. La ivermectina (IVM) es ampliamente utilizada para el control de parásitos en el ganado en los trópicos. La IVM residual en las heces conserva su actividad insecticida durante semanas y puede dañar diversas especies de escarabajos estercoleros. La atracción a las heces del ganado tratado con IVM se probó usando a las especies Onthophagus landolti (Harold) y Canthon indigaceus chevrolati (Harold) como modelos de estudio. Los experimentos se realizaron bajo condiciones de laboratorio controladas, condiciones de campo semicontroladas y condiciones de campo no controladas. Se utilizaron olfatómetros en los ensayos controlados y semicontrolados. El tratamiento de control consistió en heces exentas de IVM, y los tratamientos experimentales fueron heces de ganado tratado con IVM al $1 \%$ (administración subcutánea, dosis única, $0.2 \mathrm{mg} /$ $\mathrm{kg} \mathrm{pv)} \mathrm{las} \mathrm{cuales} \mathrm{se} \mathrm{recogieron} \mathrm{a} \mathrm{los} \mathrm{5,} \mathrm{14,} 21$ y 28 días después del tratamiento al ganado. El ensayo de campo no controlado incluyó trampas de caída libre o pitfall cebadas con heces libres de IVM y con heces de ganado tratado con IVM recogido cinco días después del tratamiento. En condiciones controladas y semicontroladas, las heces del ganado tratado con IVM (a los 5, 14, 21 y 28 días después del tratamiento) atrajeron más individuos $O$. landolti y C. $i$. chevrolati que las heces $\sin$ IVM $(\mathrm{P}<0.05)$. La misma respuesta ocurrió bajo condiciones no controladas. Esta clara atracción a las heces de ganado que contienen IVM por las especies estudiadas pone de relieve que el uso incorrecto de IVM puede plantear un riesgo para las comunidades de escarabajos estercoleros en los sistemas de producción ganadera.

Palabras clave: Ivermectina; heces de ganado; escarabajos estercoleros; atracción; condiciones controladas; condiciones de campo; olfatómetro. 


\section{REFERENCES}

Basto-Estrella, G. S., Rodríguez-Vivas, R. I., Delfín-González, H., \& Reyes-Novelo, E. A. (2012). Escarabajos estercoleros (Coleoptera: Scarabaeinae) en ranchos de Yucatán, México. Revista Mexicana de Biodiversidad, 83, 380-386.

Basto-Estrella, G. S., Rodríguez-Vivas, R. I., Delfín-González, H., \& Reyes-Novelo, E. A. (2014). Dung beetle (Coleoptera: Scarabaeinae) diversity and seasonality in response to macrocyclic lactones use at cattle ranches in the Mexican Neotropics. Insect Conservation and Diversity, 7, 73-81.

Bautista, F., Batllori, E., Palacio, G., Ortiz, M., \& Castillo, M. (2005). Integración del conocimiento actual sobre los paisajes geomorfológicos de la Península de Yucatán. En F. Bautista \& A. G. Palacio (Eds.), Caracterización y manejo de los suelos de la Península de Yucatán. Implicaciones agropecuarias, forestales y ambientales (pp. 33-58). México: UAC-UADY-INE.

Bernal, J., Nozal, M., Salas, M., Galante, E., \& Lumaret, J. (1994). HPLC determination of residual ivermectin in cattle dung following subcutaneous injection. Journal of Liquid Chromatography, 17, 2429-2444.

Dadour, I. R., Cook, D. F., \& Neesam, C. (1999.) Dispersal of dung containing ivermectin in the field by Onthophagus taurus (Coleoptera: Scarabaeidae). Bulletin of Entomological Research, 89, 119-123.

Davey, R. B., Pound, M. J., Miller, A. J., \& Klavons, J. A. (2010). Therapeutic and persistent efficacy of a longacting (LA) formulation of ivermectin against $R h i$ picephalus (Boophilus) microplus (Acari: Ixodidae) and sera concentration through time in treated cattle. Veterinary Parasitology, 169, 149-156.

Decante, D., \& van Helden, M. (2008). Spatial and temporal distribution of Empoasca vitis within a vineyard. Agricultural and Forest Entomology, 10, 111-118.

Dormont, L., Jay-Robert, P., Bessière, J. M., Rapiorm, S., \& Lumaretm, J. P. (2013). Innate olfactory preferences in dung beetles. The Journal of Experimental Biology, 213, 3177-3186.

Duce, I. R., \& Scott, R. H. (1985). Actions of dihydroavermectin Bla on insect muscle. British Journal of Pharmacology, 85, 395-401.

Errouissi, F., \& Lumaret, J. P. (2010). Field effects of faecal residues from ivermectin slow- release boluses on the attractiveness of cattle dung to dung beetles. Medical and Veterinary Entomology, 24, 433-440.

Finch, S. (1986). Assessing Host-Plant Finding by Insects. In J. R. Miller, \& T. A. Miller (Eds.), Insect-Plant Interactions (pp. 23-63). New York: Springer Series in Experimental Entomology.
Floate, K. D. (1998a). Does a repellent effect contribute to reduced levels of insect activity in dung from cattle treated with ivermectin? Bulletin of Entomology Research, 88(3), 291-297.

Floate, K. D. (1998b). Off-target effects of ivermectin on insects and on dung degradation in southern Alberta, Canada. Bulletin of Entomology Research, 88(1), 25-35.

Floate, K. D. (2006). Endectocide use in cattle and fecal residues: environmental effects in Canada. The Canadian Journal of Veterinary Research, 70, 1-10.

Floate, K. D. (2007). Endectocide residues affect insect attraction to dung from treated cattle: implications for toxicity tests. Medical and Veterinary Entomology, $21,312-322$.

Floate, K. D. (2011). Arthropods in Cattle Dung on Canada's Grasslands. In K. D. Floate (Ed.), Arthropods of Canadian Grasslands: Inhabitants of a Changing Landscape (Vol. 2, pp. 71-88). Canada: Biological Survey of Canada.

Floate, K. D., Wardhaugh, K. G., Boxall, A. B. A., \& Sherratt, T. N. (2005). Fecal residues of veterinary parasiticides: nontarget effects in the pasture environment. Annual Review of Entomology, 50, 153-179.

García-Gil, G., Méndez-González, L., Aguilar-Cordero, W., \& Orellana-Lanza, R. (2010). Ambientes terrestres. En R. Durán \& M. Méndez (Eds.), Biodiversidad y Desarrollo Humano en Yucatán (pp. 17-20). Mérida, Mexico: CICY, PPD-FMAM, CONABIO, SEDUMA.

González-Tokman, D., Martínez, M. I., Villalobos-Avalos, Y., Munguía-Steyer, R., Ortiz-Zayas, M. D., CruzRosales, M., \& Lumaret, J. P. (2017). Ivermectin alters reproductive success, body condition and sexual trait expression in dung beetles. Chemosphere, 178, 129-135.

Holter, P., Sommer, C., \& Grønvold, J. (1993a). Attractiveness of dung from ivermectin-treated cattle to Danish and afrotropical scarabaeid dung beetles. Veterinary Parasitology, 48, 159-169.

Holter, P., Sommer, C., Grønvold, J., \& Madsen, M. (1993b). Effects of ivermectin treatment on the attraction of dung beetles (Coleoptera: Scarabaeidae and Hydrophilidae) to cowpats. Bulletin of Entomology Research, 83(1), 53-58.

Kane, N. S., Hirschberg, B., Qian, S., Hunt, D., Thomas, B., Brochu, R., ... Cully, D. F. (2000). Drug-resistant Drosophila indicate glutamate-gated chloride cha nnels are targets for the antiparasitics nodulisporic acid and ivermectin. Proceedings of the National Academy of Sciences of the United States of America, 97. 13949-13954. 
Krüger, K., \& Scholtz, C. (1998). Changes in the structure of dung insect communities after ivermectin usage in a grassland ecosystem. II. Impact of ivermectin under high-rainfall conditions. Acta Oecologica, 19(5), 439-451.

Lee, C. M., \& Wall, R. (2006). Cow-dung colonization and decomposition following insect exclusion. Bulletin of Entomological Research, 96, 315-322.

Lobo, J. M., Martin-Piera, F., \& Veiga, C. M. (1988). Las trampas pitfall con cebo, sus posibilidades en el estudio de las comunidades coprófagas de Scarabaeoidea (Col.). I. Características determinantes de su capacidad de captura. Revue d'écologie et de Biologie du Sol, 25(1), 77-100.

Lumaret, J. P., Galante, E., Lumbreras, C., Mena, C., Bertrand, M., Bernal, J. L., Cooper, J. F., Kadiri, N., \& Crowe, D. (1993). Field effects of antiparasitic drug ivermectin residues on dung beetles (Insecta, Coleoptera). Journal of Applied Ecology, 30, 428-436.

Mackie, R., Stroot, P., \& Varel, V. (1998). Biochemical identification and biological origin of key odour components in livestock waste. Journal of Animal Science, 76, 1331-1342.

Martínez, M. I., Lumaret, J. P., Ortiz Zayas, R., \& Nassera Kadiri, M. (2017a). The Effects of Sublethal and Lethal Doses of Ivermectin on the Reproductive Physiology and Larval Development of the Dung Beetle Euoniticellus intermedius. The Canadian Entomologist, 149(4), 461-472.

Martínez, M. I., Ramírez-Hernández, A., \& Lumaret, J. P. (2017b). Medicinas Veterinarias, Plaguicidas, y los Escarabajos del Estiércol en la Zona Tropical de Palma Sola, Veracruz, México. Southwestern Entomologist, 42(2), 563-574.

Morón, M. A. (2003). Atlas de los escarabajos de México. Coleoptera: Lamellicornia,. Familias Scarabaeidae, Trogidae, Passalidae y Lucanidae (Vol. 2). Argania, Barcelona: Argania Editio.

Nichols, E. S., \& Gardner, T. A. (2011). Dung beetles as a candidate study taxon in applied biodiversity conservation research. In L. W. Simmons \& T. J. RidsdillSmith (Eds.), Ecology and Evolution of Dung Beetles (pp. 267-291). Oxford, UK: Wiley-Blackwell.

Nichols, E., Spector, S., Louzada, J., Larsen, T., Amezquita, S., Favila, M. E., \& The Scarabaeinae Research Network. (2008). Ecological functions and ecosystem services provided by Scarabaeinae dung beetles. Biological Conservation, 141, 1461-1474.

Orellana-Lanza, R., Espadas-Manrique, C., \& Nava-Marín, F. (2010). Climas. En R. Durán \& M. Méndez (Eds.), Biodiversidad y Desarrollo Humano en Yucatán (pp. 10-11). Mérida, México: CICY, PPD-FMAM, CONABIO, SEDUMA.
Panek, I., Meisner, S., \& Torkkeli, P. H. (2003). Distribution and function of GABAB receptors in spider peripheral mechanosensilla. Neurophysiology, 90, $2571-2580$

Pérez-Cogollo, L. C., Rodríguez-Vivas, R. I., DelfínGonzález, H., Reyes-Novelo, E., \& Ojeda-Chi, M. (2015). Lethal and Sublethal Effects of Ivermectin on Onthophagus landolti (Coleoptera: Scarabaeidae). Environmental Entomology, 44(6), 1634-1640.

Pérez-Cogollo, L. C., Rodríguez-Vivas, R. I., Reyes-Novelo, E., Delfín-González, H., \& Muñoz-Rodríguez, D. (2017). Survival and reproduction of Onthophagus landolti (Coleoptera: Scarabaeidae) exposed to ivermectin residues in cattle dung. Bulletin of Entomological Research, 107, 118-125.

Pernal, S. F., \& Currie, R. W. (2002). Discrimination and preferences for pollen-based cues by foraging honeybees, Apis mellifera L. Animal Behaviour, 63, 369-390.

Pfeiffer, K., Torkkeli, P. H., \& French, A. S. (2013). Activation of GABAA receptors modulates all stages of mechanoreception in spider mechanosensory neurons. Journal of Neurophysiology, 107, 196-204.

R Core Team. (2016). $R$ : A language and environment for statistical computing. $R$ Foundation for Statistical Compitung, Vienna, Austria. Retrieved from https:// www.R-project.org/

Ranjith, A. M. (2007). An inexpensive olfactometer and wind tunnel for Trichogramma chilonis Ishii (Trichogrammatide: Hymenoptera). Journal of Tropical Agriculture, 45(1-2), 63-65.

Rodríguez-Vivas, R. I., Arieta-Román, R. J., Pérez-Cogollo, L. C., Rosado-Aguilar, J. A., Ramírez-Cruz, G. T., \& Basto-Estrella, G. (2010). Uso de lactonas macrocíclicas para el control de la garrapata Rhipicephalus (Boophilus) microplus en el ganado bovino. Archivos de Medicina Veterinaria, 42, 115-123.

Römbke, J., Barrett, K., Blanckenhorn, W. U., Hargreaves, T., Kadiri, N., Knäbe, S., ... Sekine, T. (2010). Results of an international ring test with the dung fly Musca autumnalis in support of a new OECD test guideline. Science of the Total Environment, 408(19), 4102-4106.

Schaper, R., \& Liebisch, A., (1991). Einflußeines systemis chwirkenden Antiparasitikums (Ivermectin) auf die dung fauna und den Dungabbau der Rinderbei Weidehaltung. Tierärztliche Umschau, 46, 12-18.

Steinfeld, H., Gerber, P., Wassenaar, T., Castel, V., Rosales, M., \& Haan, C. (2006). Livestock's long shadow: environmental issues and options, Food and Agriculture Organization of the United Nations. Rome: FAO.

Suarez, V., Lifschitz, A., Sallovitz, A., \& Lanusse, C. (2003). Effects of ivermectin and doramectin faecal residues on the invertebrate colonization of cattle dung. Journal of Applied Entomology, 127, 481-488. 
Sutton, G., Bennett, J., \& Bateman, M. (2014). Effects of ivermectin residues on dung invertebrate communities in a UK farmland habitat. Insect Conservation and Diversity, 7, 64-72.

Tovar, H. L., Noriega, J. A., \& Caraballo, P. (2016). Ivermectin effect on the structure of the ensembles of dung beetles (Coleoptera: Scarabaeidae: AphodiinaeScarabaeinae) in the Colombian savannahs of the Caribbean region. Actualidades Biológicas, 38(105), 157-166.

Tumlinson, J. H., Lewis, W. J., \& Vet, L. E. M. (1993) How parasitic wasps find their host. Scientific American, 268, 100-106.

Verdú, J. R., Cortez, V., Ortiz, A. J., González-Rodríguez, E., Martinez-Pinna, J., Lumaret, J. P., ... SánchezPiñero, F. (2015). Low doses of ivermectin cause sensory and locomotor disorders in dung beetles. Scientific Reports, 5(13912), 1-10.

Verdú, J. R., Lobo, J. M., Numa, C., Pérez-Ramos, I. M., Galante, E., \& Marañon, T. (2007). Acorn preference by the dung beetle, Thorectes lusitanicus, under laboratory and field conditions. Animal Behaviour, 74, 1697-1704.

Verdú, J. R., Lobo, J. M., Sánchez-Piñero, F., Gallego, B., Numa, C., Lumaret, J. P., ... Durán, J. (2017). Ivermectin residues disrupt dung beetle diversity, soil properties and ecosystem functioning: An interdisciplinary field study. Science of the Total Environment, 618(2018), 219-228

Wall, R., \& Beynon, S. (2012). Area-wide impact of macrocyclic lactone parasiticides in cattle dung. Medical and Veterinary Entomology, 26, 1-8.

Wardhaugh, K. G., \& Mahon, R. J. (1991). Avermectin residues in sheep and cattle dung and their effects on dung beetle colonisation and dung burial. Bulletin of Entomology Research, 81(3), 333-339.

Webb, L., Beaumont, D., Nager, R., \& McCracken, D. (2010). Field-scale dispersal of Aphodius dung beetles (Coleoptera: Scarabaeidae) in response to avermectin treatments on pastured cattle. Bulletin of Entomological Research, 100, 175-183. 